\title{
Hearing Results After Type I Tympanoplasty With Versus Without Mastoidectomy
}

\author{
Jun Young Lee ${ }^{1}$, Sung-Kwang Hong ${ }^{1,2}$, Hyo-Jeong Lee ${ }^{1,2}$, \\ Jong Kyou Lee, and Hyung-Jong Kim ${ }^{3,2}$ (i) \\ ${ }^{I}$ Department of Otorhinolaryngology-Head and Neck Surgery and ${ }^{2}$ Laboratory of Brain \& Cognitive Sciences for Convergence Medicine, \\ Hallym University College of Medicine, Anyang; and ${ }^{3}$ Department of Otorhinolaryngology-Head and Neck Surgery, \\ Kangnam Sacred Heart Hospital, Hallym University College of Medicine, Seoul, Korea
}

\author{
유돌절제술 여부에 따른 제1형 고실성형술 후 청력결과 \\ 이준영 ${ }^{1} \cdot$ 홍성광 $^{1,2} \cdot$ 이효정 ${ }^{1,2} \cdot$ 이종규 $^{3} \cdot$ 김형종 $^{1,2}$ \\ 한림대학교 의과대학 ${ }^{1}$ 이비인후-두경부외과학교실, ${ }^{2}$ 뇌인지융합의학연구소, \\ ${ }^{3}$ 한림대학교 의과대학 강남성심병원 이비인후-두경부외과학교실
}

\author{
Received September 9, 2020 \\ Revised November 16, 2020 \\ Accepted November 16, 2020 \\ Address for correspondence \\ Hyung-Jong Kim, MD, PhD \\ Department of Otorhinolaryngology- \\ Head and Neck Surgery, \\ Hallym University \\ College of Medicine, \\ 22 Gwanpyeong-ro 170beon-gil, \\ Dongan-gu, Anyang 14068, Korea \\ Tel $+82-31-380-3849$ \\ Fax $+82-31-386-3860$ \\ E-mail hjk1000@hallym.or.kr
}

Background and Objectives The purpose of the mastoidectomy and tympanoplasty is to improve the hearing by removing the middle ear lesion and reconstructing the hearing mechanism. The purpose of this study is to verify whether several factors, including the presence of mastoidectomy can affect the hearing outcome of tympanoplasty patients.

Subjects and Method From 1989 to 2018, 1260 patients with chronic otitis media who had been followed up for more than 6 months after type 1 tympanoplasty were selected. The each patient group was divided into 2 groups based on the last audiometry; Group A (post operative air-bone gap $[\mathrm{ABG}] \leq 10 \mathrm{~dB} \mathrm{HL}$ ) and Group $\mathrm{B}$ (post operative $\mathrm{ABG}>10 \mathrm{~dB} \mathrm{HL}$ ). We analyzed the various factors including patency of E-tube or mastoid aeration for each group to figure out which factors affect the post operative hearing outcome.

Results In conclusion, even with mastoidectomy, the final hearing after surgery was worse than that of the group who underwent tympanoplasty only (final ABG; tympanoplasty only vs. tympanoplasty with mastoidectomy; $6.59 \pm 9.09$ vs. $9.71 \pm 8.94)$. In both with and without mastoidectomy group, the size of the perforation and external ear canal diameter before surgery did not affect the final hearing outcome. On the otherhand, in the group with mastoidectomy, mastoid pneumatization and E-tube patency affected the postoperative prognosis, but not in the case without mastoidectomy.

Conclusion In this study, the factors affecting postoperative hearing success were analyzed. The results can be used to predict the postoperative hearing prognosis and to help select surgical treatment.

Korean J Otorhinolaryngol-Head Neck Surg 2021;64(11):785-91

\section{서 론}

만성 중이염은 이비인후과 외래에서 흔히 접하는 질환으로 고막결손과 중이병변에 의한 난청 및 이루를 주증상으로 하
며, 보존적 약물치료를 하는 경우도 있지만, 근본적 원인질환 제거를 위해서는 수술적 치료를 시행하게 된다. ${ }^{1)}$ 만성 중이염 에 대한 수술적 치료로서 시행되는 유돌절제술은 비가역적 유돌부 병변의 제거와 청각재건을 목적으로 하며, 흔히 동반

This is an Open Access article distributed under the terms of the Creative Commons Attribution Non-Commercial License (https:/creativecommons.org/licenses/by-nc/4.0) which permits unrestricted non-commercial use, distribution, and reproduction in any medium, provided the original work is properly cited. 
하는 고막성형술은 제 1 형 고실성형술이라고도 하며 고막 재 생을 통해 반복되는 중이 염증을 예방하고, 소리에너지를 이 소골을 통해 내이로 효율적으로 전달함으로써 술후 청력개 선을 목표로 한다. ${ }^{2)}$ 유돌절제술은 만성 중이염 치료로써 흔히 시행되는 술식으로 유돌절제술만 단독적으로 시행되는 경우 도 있으나, 대부분 천공된 고막과 파괴된 이소골 재건을 도모 하고자 고실성형술을 동반한다.

만성 중이염에서 고막천공이 발생할 경우 전음성 난청을 보이게 되며, ${ }^{3)}$ 고막성형술의 술후 청력예후에 대하여 중이염 또는 재발성 천공을 포함한 술전 인자에 대한 연구는 흔히 있 었으나, 유돌절제술을 동반할 때 술후 청력에 미치는 인자에 대한 연구는 많지 않았고, 특히, 단독 술자에 의해 장기간에 걸쳐서 시행된 대규모 수술예에 대한 예후인자 분석연구는 현재까지 찾아보기 힘들다.

본 연구에서는 유돌절제술을 동반하거나 또는 동반하지 않은 예를 포함한 제1형 고실성형술을 대상으로 술후 청력결 과에 영향을 미치는 인자를 알아보고자 하였다. 술후 성공적 청력(postoperative hearing success) 여부에 따라 성공군과 실패군으로서 분류하고 다양한 예후 인자별 분석을 통해, 각 군에서 제1형 고실성형술의 술후 청력 예후에 미치는 인자에 대해 분석하고자 하였다.

\section{대상 및 방법}

\section{대 상}

1989년 5월부터 2018년 12월까지 강동성심병원 및 한림대 학교성심병원에서 만성 중이염으로 1 인 술자에 의해 제 1 형 고 실성형술을 시행 받은 후 6 개월 이상 청력결과 추적이 된 환 자를 대상으로 후향적 연구를 실시하였다. 수술 대상군은, 이 소골 미란을 동반하지 않는 단순 만성 중이염 혹은 일부 진 주종성 중이염 환자군이 포함되었으며, 이소골 미란을 동반 하여, 이소골 성형술을 동반한 환자군은 제외하였다. 각 예 들에 대해 수술기록을 포함한 병원의무기록과 함께 2005년 대한이과학회에서 배포한 중이수술 데이터베이스에 저장되 고 관리된 자료를 이용하여 후향적 분석을 시행하였다. 본 연 구는 본원의 임상시험연구심사위원회(Institutional Review Board)의 검토와 승인을 얻은 후 진행하였다(HALLYM 2020-06-002-001).

\section{방 법}

연구에 포함된 모든 예에서 수술 전 청력검사 및 고실도 검 사, 이내시경 검사 및 측두골 전산화단층촬영을 시행하였다. 청력검사는 수술 전, 술후 1 개월, 3 개월, 6 개월, 1 년, 그 후로
매년마다 추적 검사를 시행하였고 미국 이비인후과학회 기준 (AAO-NHS standard, 1995)을 따라 순음청력역치 0.5, 1, 2, $3 \mathrm{kHz}$ 의 평균인 4 분법을 이용하여 기도청력과 골도청력, 및 기도-골도차를 측정 계산하였으며, $3 \mathrm{kHz}$ 가 측정되지 않은 예에서는 $2,4 \mathrm{kHz}$ 의 평균 역치를 이용하여 측정하였다. 이관 기능은 술전 발살바 이관통기법을 이용해 평가하였다. 또한, 의무기록 및 중이수술 데이터베이스(2005)에 저장된 수술소 견 기록을 바탕으로 고막 및 중이의 병변, 이소골 상태, 유돌 절제술 종류 등을 분류하여 비교하였다.

술전 시행한, 내시경 검사 소견을 참고하여 외이도 크기와 고막 천공의 크기를 분류하였으며, 외이도 크기는 외부 시야 에서 골부 bulging에 의해 고막륜이 안 보이면 small diameter, 그렇지 않으면 moderate/big diameter라고 분류하였고, 고막천공 크기는 내시경 고막소견상 천공의 면적이 전체의 $50 \%$ 미만일 경우를 소천공, $50 \%$ 이상일 경우를 대천공, 그리 고, 고막륜이 없는 경우를 전천공으로 분류하였다. 이관기능 의 경우, Valsalva 이관통기법시 환측 귀로 유입된 공기가 외 이도로 누출되는 소견을 보이면 정상, 누출 소견이 없는 경우 에는 이관 폐쇄로 판정하였다. 술전 시행한 측두골 전산화단 층촬영을 참고하여 유양동 함기화를 유양동이 골화된 경화 형과 비교적 양호한 판상형/함기형으로 분류하였고, 유돌동 구 개방상태는 수술소견을 참고하여 개방과 폐쇄로 분류하 였으며, 수술 시 관찰한 중이 점막의 비후 및 부종 소견의 여 부, 이소골의 미란 및 고정 여부를 기준으로 하여 중이강의 상태를 분류하였다.

먼저, 첫째, 유돌절제술의 여부에 따른 술후 결과를 알아보 기 위해 유돌절제술을 동반한 군과 그렇지 않은 군으로 나누 었으며, 각 군을 대상으로, 수술 전후 청력 및 술후 재천공의 발생여부 그리고, 술후 성공적인 청력의 달성여부를 조사하 였다. 또한 각 군에 대해, 술후 추적된 예의 최종 순음청력검 사 결과를 기준으로, 술후 최종 기도-골도차가 $10 \mathrm{~dB}$ 이하로 되어 청각기전의 재건에 성공했다고 판단한 성공군 $(\mathrm{A}$ 군)과 술후 기도-골도차가 $10 \mathrm{~dB}$ 를 초과하여 청각기전 재건에 실 패했다고 판단한 실패군(B군)으로서 임의로 정의하였고, 성 공군과 실패군에 영향을 미치는 인자들을 각각 비교하였다. 둘째, 고실성형술 단독 시행군의 경우 연구대상의 이관기능, 청력상태, 외이도 크기, 고막 및 중이 병변, 이소골 상태, 유양 동의 함기화 정도 및 재수술 여부 등을 비교하였고, 셋째, 유 돌절제술을 동반하여 시행한 군에서는 그와 더불어 유돌동 구 개방 상태와 유돌절제술 종류와의 연관성도 추가적으로 분석하였다. 


\section{통계 분석}

SPSS 26 (IBM Corp., Armonk, NY, USA) 프로그램을 이 용하여 통계학적 분석을 시행하였고, 한림대학교의료원 중앙 임상의학연구소 의학통계실의 자문을 받아 술후 청력예후에 따른 각 군을 t-test 및 카이제곱 검정법을 사용하여 비교하 였다. 또한 인자와 술후 청력 간의 인과관계에 대해서는 교란 변수에 의한 영향을 배제하기 위해, 로지스틱 회귀분석을 사 용하였으며, $p$-value가 0.05 이하를 통계학적으로 유의한 차 이로서 정의하였다.

\section{결 과}

해당 기간에 시행된 제1형 고실성형술은 고실성형술만을 시행한 1191예와 유돌절제술과 함께 시행한 1832예를 포함 하여 총 3023예였다. 이들 전체 환자군에서의 평균 마지막 청 력 검사 시행 기간은 $28.91 \pm 45.20$ 개월이었고, 이들 중 6 개월 이상 청력결과 추적이 가능하여, 본 연구 대상에 포함된 예 는 총 1260예로 술전 기도-골도 청력차가 $10 \mathrm{~dB}$ 미만인 환자 238예가 포함되었고, 제1형 고실성형술만을 시행한 446예와 유돌절제술을 함께 시행한 814예가 있었다(Fig. 1).

\section{유돌절제술의 동반 유무에 따른 비교}

유돌절제술을 동반한 군과 그렇지 않은 군을 기준으로 비 교하였을 때, 두 군 간의 성별, 나이, 수술귀의 방향에서는 유의한 차이를 보이지 않았다. 제 1 형 고실성형술만을 단독적 으로 시행하였을 경우 수술 전, 후 기도-골도청력차는 각각 $15.40 \pm 9.59 \mathrm{~dB} \mathrm{HL}, 6.59 \pm 9.09 \mathrm{~dB} \mathrm{HL}$ 이었고, 유돌절제술을 동반한 경우는 각각 $22.61 \pm 10.15 \mathrm{~dB} \mathrm{HL}, 9.71 \pm 8.94 \mathrm{~dB} \mathrm{HL}$ 로 측정되어 유돌절제술을 동반하지 않은 경우 수술 전, 후
기도-골도차가 유의하게 낮았다 $(p<0.05)$. 이때, 술후 기도골도차 청력의 개선정도는 유돌절제술 동반 군에서 유의하게 높게 나타났다. 수술 후 발생한 천공의 재발 여부를 보았을 때, 유돌절제술을 동반하지 않았을 경우, 술후 정상적인 고막 소견을 보인 예가 446예 중 36예(8\%), 유돌절제술을 동반한 경우는 814예 중 164 예(20\%)로, 두 군 간의 차이를 카이 제곱 검정을 통해 유의성을 검정하였고, 고막성형술만을 시행한 경 우 천공의 재발 비율이 더 낮았다 $(p<0.05)$ (Table 1).

수술 후 성공적인 청력재건의 여부를 보았을 때, 유돌절제 술을 동반하지 않았을 경우 술후 $10 \mathrm{~dB}$ 이하의 재건에 성공 한 예가 446예 중 347예(77.8\%), 유돌절제술을 동반한 경우 는 814예 중 507예(62.3\%)로, 유돌절제술을 동반하지 않은 예에서 청력재건에 성공한 비율이 더 높았다. 술전 시행한 기 도-골도 청력차의 영향을 배제하기 위해, 술전 기도-골도 청 력차와 유돌절제 여부에 대한 로지스틱 회귀 분석모형을 사 용하여 분석하였고, 두 군에서는 유의한 차이가 나타남을 확 인할 수 있었다 $(p<0.05)$ (Table 1).

\section{유돌절제술을 동반한 예}

제1형 고실성형술과 유돌절제술을 동반하여 시행한 814예 중, 수술 후에 성공적인 청력개선을 보인 $\mathrm{A}$ 군은 총 507예였 고, 그렇지 않은 B군은 총 307예였다. A군의 술전 골도, 기도 청력 및 기도-골도 청력차는 각각 $21.73 \pm 13.56 \mathrm{~dB} \mathrm{HL}, 41.39 \pm$ $15.37 \mathrm{~dB} H L$ 및 $19.61 \pm 8.97 \mathrm{~dB}$ 이었고, $\mathrm{B}$ 군은 각각 $24.42 \pm$ 15.37 dB HL, 51.94 $\pm 18.20 \mathrm{~dB}$ HL 및 27.56 $\pm 10.05 \mathrm{~dB}$ HL 로 측정되어 양군간 골도 청력은 유의한 차이를 보이지 않았 으나, 기도청력 및 기도-골도 청력차는 $\mathrm{A}$ 군이 $\mathrm{B}$ 군보다 작았 고, 유의한 차이를 보였다 $(p<0.05)$.

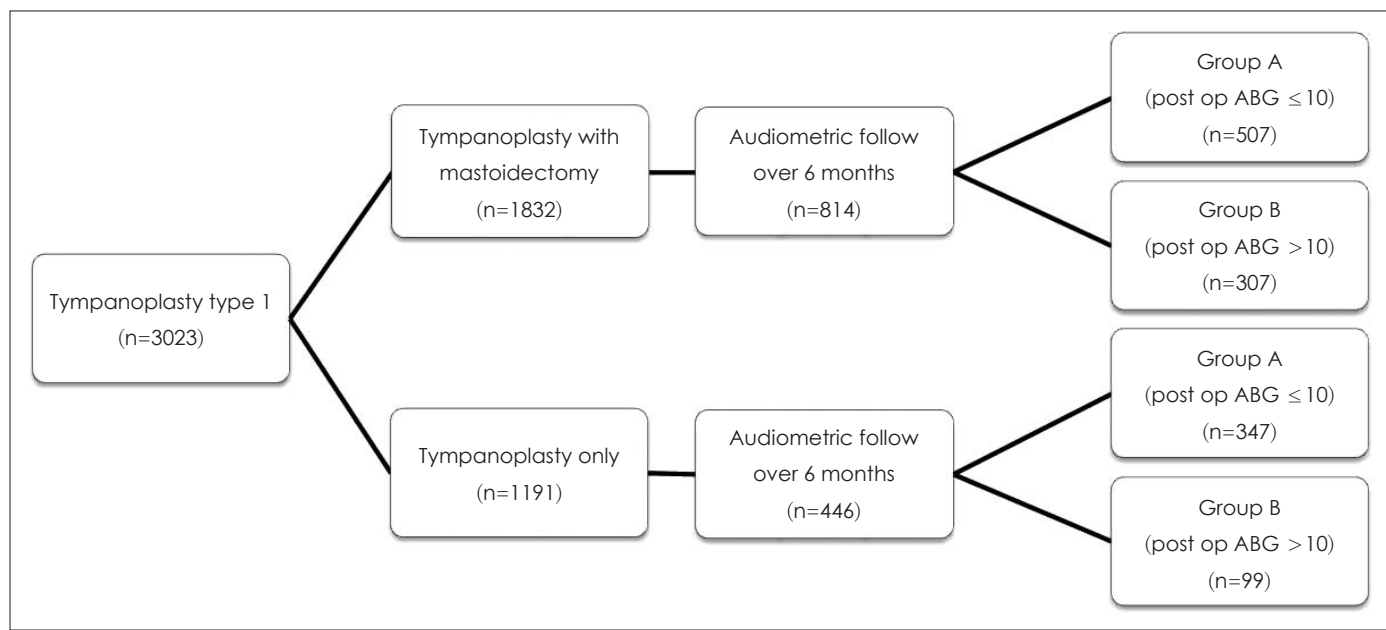

Fig. 1. Cases of tympanoplasty type 1 with or without mastoidectomy from 1989 to 2018 . ABG, air-bone gap. 
Table 1. Comparison between tympanoplasty only cases and tympanoplasty with mastoidectomy cases

\begin{tabular}{|c|c|c|c|}
\hline & \multicolumn{3}{|c|}{ Hearing outcome } \\
\hline & Tympanoplasty only $(n=446)$ & Tympanoplasty with mastoidectomy $(n=814)$ & $p$ value \\
\hline Sex & & & $>0.05$ \\
\hline Male & $170(38)$ & $276(34)$ & \\
\hline Female & $276(62)$ & $538(66)$ & \\
\hline Age (year) & $45.59 \pm 15.94$ & $48.21 \pm 13.30$ & $>0.05$ \\
\hline Direction & & & $>0.05$ \\
\hline Right & $221(50)$ & 401 (49) & \\
\hline Left & $225(50)$ & $413(51)$ & \\
\hline Pre-operative ABG (dB HL) & $15.40 \pm 9.59$ & $22.61 \pm 10.15$ & $<0.05$ \\
\hline Post-operative $\mathrm{ABG}(\mathrm{dB} \mathrm{HL})$ & $6.59 \pm 9.09$ & $9.71 \pm 8.94$ & $<0.05$ \\
\hline Perforation closure & & & $<0.05$ \\
\hline Success & $410(92)$ & $650(80)$ & \\
\hline Failure & $36(8)$ & $164(20)$ & \\
\hline Hearing outcome & & & $<0.001$ \\
\hline Success $(A B G \leq 10 \mathrm{~dB})$ & $347(77.8)$ & $507(62.3)$ & \\
\hline Failure $(\mathrm{ABG}>10 \mathrm{~dB})$ & 99 (22.2) & $307(37.7)$ & \\
\hline
\end{tabular}

Data are presented as $n(\%)$ or mean $\pm S D$. ABG, air-bone gap

\section{술후 청력 결과와 관련된 인자}

성공군(A)과 실패군(B)에서의 술전, 술중 인자를 비교하였 다. 이때, 성공군의 술전 기도-골도 청력차가 유의하게 낮아, 술전 시행한 기도-골도 청력차의 영향을 배제하기 위해, 술 전 기도-골도 청력차와 각 인자에 대한 로지스틱 회귀분석모 형을 사용하여 분석하였다(Table 2).

각 인자들을 살펴보았을 때 청력재건에 성공했다고 판단 한 $\mathrm{A}$ 군에서 $\mathrm{B}$ 군보다 유동적인 이소골 움직임을 보이는 비율 이 높았고, 고실경화반을 포함한 비율이 낮았으며, 경화상 유 양동의 비율이 낮았고, 이관 기능 및 유돌동구의 개존 상태 가 양호했다. 또한, $\mathrm{B}$ 군에서 개방동 유돌절제술을 시행한 환 자의 비율이 더 높았다 $(p<0.05)$.

반면, 외이도의 협착 여부, 재수술 여부, 고막 천공의 크기는 양 군 간의 유의한 차이를 보이지 않았다 $(p>0.05)$ (Table 2).

\section{유돌절제술을 동반하지 않은 예}

유돌절제술을 동반하지 않고 고막성형술만을 시행한 446 예 중 수술 후에 성공적인 청력개선을 보인 $\mathrm{A}$ 군은 총 347 예 (77\%)였으며, 그렇지 않은 B군은 총 98예(23\%)였다. A군의 술전 기도청력과 기도-골도 청력차는 각각 $32.8 \pm 15.8 \mathrm{~dB} \mathrm{HL}$ 및 $13.0 \pm 7.9 \mathrm{~dB}$ HL이었고, $\mathrm{B}$ 군은 각각 $48.6 \pm 23.3 \mathrm{~dB} \mathrm{HL}$ 및 $23.6 \pm 10.43 \mathrm{~dB}$ HL로 측정되어 양 군 간의 기도청력 및 기도골도 청력차에서 $\mathrm{A}$ 군이 $\mathrm{B}$ 군보다 유의하게 좋았다 $(p<0.05)$.

\section{술후 청력 결과에 영향을 미치는 인자}

성공군(A)과 실패군(B)에서의 술전, 술중 인자를 비교하였
으며, 고실성형술만을 시행한 환자군 또한 성공군의 술전 기 도-골도 청력차가 유의하게 낮았기에, 술후 결과에 영향을 미칠 수 있는 교란변수로 작용할 수 있음을 감안하여 이를 보정한 로지스틱 회귀분석을 시행하였다(Table 3).

성공군(A)에서 실패군(B)에 비해 유동적인 이소골 움직임 을 가진 환자 비율 및 초수술 환자의 비율이 높았으며, 그 외 유양동의 함기화, 이관기능, 중이 점막의 상태, 술전 천공의 크기 및 외이도의 협착 여부는 양 군 간 유의한 차이를 보이 지 않았다(Table 3).

\section{고 찰}

유돌절제술과 고실성형술의 목적은 중이 및 유양동 병변 을 제거함으로써 추후 발생할 수 있는 감염의 재발방지 및 청력기전의 재건을 통한 청력개선 도모에 있으므로 감염 등 에 의한 천공의 재발, 그리고 술후 청력은 수술의 예후 판정 에 중요한 지표가 될 수 있다. ${ }^{4)}$ 고실성형술 후 청력예후에 대 해서는 $76 \%$ 의 환자가 술후 기도-골도 청력차가 $15 \mathrm{~dB}$ 미만 으로 보고한 연구가 있고, ${ }^{5)}$ 그 외 Claes 등은 $79.6 \%$ 에서 술 후 순음청력검사상 기도 골도 역치 차가 $21 \mathrm{~dB}$ 미만임을 보 고한 바 있으며, 국내에서는 Kim 등기 제 1형 고실성형술 1 년 후 시행한 청력검사상 $87 \%$ 의 환자가 기도-골도차 청력이 $20 \mathrm{~dB}$ 미만임을 보고한 바 있다. 본 연구에서는 수술 후 측 정한 기도-골도차 청력이 만성 중이염으로 인해 손상된 청력 기전의 회복 여부를 판단할 수 있는 지표가 될 것으로 판단하 고, 기도-골도차를 기준으로 하여 예후를 양호한 군과 불량 
Table 2. Factors related to hearing outcomes (tympanoplasty with mastoidectomy cases)

\begin{tabular}{|c|c|c|c|}
\hline & $\mathrm{Hec}$ & ig outcome & \\
\hline & $\begin{array}{c}\text { Group A } \\
(A B G \leq 10) \\
(n=507)\end{array}$ & $\begin{array}{c}\text { Group B } \\
(A B G>10) \\
(n=307)\end{array}$ & $p$ value \\
\hline Ossicle movement & & & 0.038 \\
\hline Mobile & $480(94)$ & $264(85)$ & \\
\hline Fixed & $27(6)$ & $43(15)$ & \\
\hline Tympanic membrane & & & 0.021 \\
\hline $\operatorname{TSP}(+)$ & $68(13)$ & $63(20)$ & \\
\hline $\operatorname{TSP}(-)$ & $439(87)$ & $244(80)$ & \\
\hline Mastoid pneumatization & & & 0.002 \\
\hline Pneumatic or diploic & $175(34.5)$ & $86(28)$ & \\
\hline Sclerotic & $332(63.5)$ & $221(72)$ & \\
\hline E-tube patency & & & 0.014 \\
\hline Patent & $301(59)$ & $131(42)$ & \\
\hline Obstructed & $206(41)$ & $176(58)$ & \\
\hline Aditus patency & & & 0.001 \\
\hline Patent & $285(56)$ & $108(35)$ & \\
\hline Obstructed & $222(44)$ & $199(65)$ & \\
\hline Mastoidectomy type & & & 0.043 \\
\hline CWUM & $506(99.8)$ & $297(96)$ & \\
\hline CWDM & $1(0.2)$ & $10(4)$ & \\
\hline EAC diameter & & & 0.326 \\
\hline Patent & 485 (95) & 287 (93) & \\
\hline Stenotic & $22(5)$ & $20(7)$ & \\
\hline Primary vs. revision & & & 0.602 \\
\hline Primary & $499(98.4)$ & $299(97.4)$ & \\
\hline Revision & $8(1.6)$ & $8(2.6)$ & \\
\hline Perforation size & & & 0.227 \\
\hline Small & $202(40)$ & $85(27)$ & \\
\hline Large & $262(51)$ & $170(55)$ & \\
\hline Near total & $43(8)$ & $52(17)$ & \\
\hline
\end{tabular}

Data are presented as $n$ (\%). ABG, air-bone gap; TSP, tympanosclerotic plaque; CWUM, canal wall up mastoidectomy; CWDM, canal wall down mastoidectomy

한 군으로 나누어 각 대상군별로 예후인자를 비교해 보았다. 본 연구에서 기존 연구의 청력결과와 다르게 기도-골도차 10 $\mathrm{dB}$ 이하를 성공 여부 기준으로 한 것은 연구 대상이 고실성 형술 전체가 아닌 1형 고실성형술 또는 고막성형술이므로 술 후 기도-골도차가 검사오차범위 내로 닫히는 것을 성공으로 하였기 때문이다. 또한, 본 연구에서는 성공군과 실패군의 인 자를 비교할 때, 술전 기도-골도차의 영향을 보정하기 위한 로지스틱 회귀분석 모형을 사용하였는데, 이는 수술 전 시행 한 청력이 수술을 통해 교정을 하더라도 술후 청력 결과와 독 립적인 관계가 아닌 직접적인 연관성을 가진 인자임을 고려 해야 했고, 실제로 양 군에서 술전 기도-골도 차가 유의하게 차이가 났기 때문이다. 즉, 수술 후의 전음성 난청의 회복여부 에 어떠한 인자가 미치는 실질적인 영향을 비교하기 위해서
Table 3. Factors related to hearing outcomes (tympanoplasty only cases)

\begin{tabular}{|c|c|c|c|}
\hline & \multicolumn{3}{|c|}{ Hearing outcome } \\
\hline & $\begin{array}{c}\text { Group A } \\
(A B G \leq 10) \\
(n=347)\end{array}$ & $\begin{array}{c}\text { Group B } \\
(A B G>10) \\
(n=98)\end{array}$ & $p$ value \\
\hline Ossicle movement & & & 0.001 \\
\hline Mobile & $336(97)$ & $80(80)$ & \\
\hline Fixed & $11(3)$ & $18(20)$ & \\
\hline Primary vs. revision & & & $<0.001$ \\
\hline Primary & $305(88)$ & $58(60)$ & \\
\hline Revision & $42(12)$ & $40(40)$ & \\
\hline Mastoid pneumatization & & & 0.950 \\
\hline Pneumatic or diploic & $329(95)$ & $90(90)$ & \\
\hline Sclerotic & $18(5)$ & $8(10)$ & \\
\hline E-tube patency & & & 0.108 \\
\hline Patent & $269(77)$ & $54(54)$ & \\
\hline Obstructed & $78(23)$ & $44(45)$ & \\
\hline Middle ear mucosa & & & 0.130 \\
\hline Patent & $216(62)$ & $43(43)$ & \\
\hline Infected & $131(38)$ & $55(57)$ & \\
\hline Perforation size & & & 0.231 \\
\hline Large & $136(39)$ & $45(46)$ & \\
\hline Small & $211(60)$ & $53(54)$ & \\
\hline EAC diameter & & & 0.371 \\
\hline Patent & $279(80)$ & $73(75)$ & \\
\hline Stenotic & $68(20)$ & $25(25)$ & \\
\hline
\end{tabular}

는 수술 전 같은 정도의 전음성 난청을 갖고 있음을 가정한 뒤 결과를 비교함이 옳다고 생각하였기에, 술전 기도-골도차 를 교란변수로 두고, 그 영향을 배제한 뒤 비교를 시행하였다.

술후 측정한 기도-골도차 청력의 개선을 위해서는 병변의 완전한 제거를 필요로 하며, ${ }^{3)}$ 본 연구에서는 중이병변과 술후 회복에 영향을 미치는 요소들에 대한 비교를 시행하였다. 본 연구에서는 가장 흔히 사용하는 발살바 이관통기법으로써 술전 이관기능을 평가하였으며, 유돌절제술을 동반한 군에 서는 유의한 차이를 보인 반면, 동반하지 않은 군에서는 유 의한 차이를 보이지 않았고, 중이 점막의 상태 또한 술후 결 과에 차이를 보이지 않았다. 이는 기존 연구 ${ }^{4,710)}$ 들이 술후 회 복과 관련된 주요한 예후인자로 이관기능을 꼽는 것과는 다 소 상이한 결과로, 이에 대해서는 추후 추가적인 연구가 필요 한 흥미로운 결과로 생각된다.

유양동 함기화와 술후 청력과의 연관성에 대해서는 논란의 여지가 있으나, ${ }^{11,12)}$ 많은 기존 연구에서 술전 유양동의 함기화 정도가 술후 예후와 상관성을 보인다는 보고를 하였다. ${ }^{13,14)}$ 본 연구에서는 유양동 함기화의 경우 유돌절제술을 동반한 예 에서는 양 군 간 유의한 차이를 보였으나, 제 1 형 고실성형술만 시행한 예의 경우 상관성을 보이지 않았는데, 이 결과는 제 1 
형 고실성형술만을 시행한 예가 대부분 유양동의 병변을 보 이지 않았고, 따라서 함기화가 좋은 유양동이 많았기 때문인 것으로 추측된다. 혹은 이관기능의 부전 여부가 유돌절제술 을 동반한 군과 동반하지 않은 군에서 상이한 결과를 보였음 을 고려했을 때, 유양동의 함기화 정도가 이관기능의 부전과 밀접한 연관을 가진다는 기존 연구와 일치하는 결과로도 볼 수 있다.

술전 고막천공의 크기와 술후 최종청력 결과와의 연관성 에는 논란이 있다. Salviz 등, ${ }^{15)}$ Wasson 등(1)은 술전 고막천 공의 크기와 술후 청력이 연관성이 없다고 밝혔으나, Pfammatter 등은 고막성형술 후의 최종 기도-골도차가 술전 고 막천공의 크기와 큰 상관성을 보였다고 발표했다. 기존 연구 의 경우, 고막 천공의 크기가 클수록 중이 음압증강작용이 적 어져 청력소실이 많아지며, 난원창과 정원창 간의 비슷한 크 기의 힘이 같은 위상으로 전달돼 진행파의 변화를 초래하게 되어 술전 기도-골도차가 커지게 되므로 결과적인 술후 청력 에 영향을 준다 추정하였으나, ${ }^{17)}$ 본 연구에서는 양 군 간에 술전 청력을 보정하고 비교하였으며, 결과적으로 양 군에서 차이를 보이지 않았다. 이를 통해 저자는 술전 고막천공의 크 기가 술전 병변의 정도 및 전음성 난청의 정도를 대변하는 자 료로 쓰일 수는 있으나, 같은 정도의 술전 청력을 가정하였을 때, 수술을 통해 천공을 완전히 복구한 뒤에는 술전 천공의 크기가 최종적인 청력결과에는 영향을 주지 않는다고 추정 할 수 있었다.

또한, 본 연구에서는 수술 기록에 저장된 이소골의 움직임 을 하나의 예후인자로서 비교 분석하였다. 이소골의 미란 등 이 보이지 않아 제 1 형 고실성형술만을 시행하더라도 이소골 의 움직임이 좋을 경우 더 나은 청력결과를 보였으며, 술전 검 사상 이소골의 병변이 관찰되지 않더라도 술중 이소골의 움 직임을 잘 관찰함으로써 청력결과를 예측할 수 있을 것으로 생각한다.

술전 외이도 크기의 경우 술후 청력과 상관관계를 보이지 않았으며, 이는 전음성 난청에서 관찰되는 기도-골도차의 경 우 외이가 아닌 중이병변에 의해 주로 발생한다는 것을 시사 하고, 좁은 외이도의 경우 수술적으로 외이도를 넓혀주기 때 문에 기도-골도차 청력에 영향을 미치지 않았을 것으로 생 각된다.

유돌절제술의 동반에 따른 예후 비교를 해보았을 때, 유돌 절제술을 동반 시행한 군에서 술전, 후 기도-골도차가 유의 하게 컸다. 술전 청력에 의한 영향을 배제한 뒤 술후 전음성 난청의 개선 여부를 비교하였을 때에도 술후 청력개선에 성 공한 환자의 비율이 유의하게 낮았다. 즉, 같은 술전 기도-골 도 차를 가진 환자임을 가정하여도 고실 성형술만을 시행한
환자군에서 청력결과가 더 우수하였는데, 이는 유돌절제술을 동반한 군에서 병변이 심했기 때문이라고 추측할 수도 있으 나, 수술을 통한 유양돌기부 병변제거가 수술 후 청력기전의 회복에 미치는 한계를 암시하는 결과로도 볼 수 있다. 다시 말해, 병변이 심해 유돌절제술을 동반하여 시행하더라도 최 종적인 청력은 유돌절제술을 통해 개선시키는 데에는 한계가 있음을 뜻한다. 유돌절제술 유형으로서 개방동 유돌절제술과 폐쇄동 유돌절제술 간의 술후 청력결과에 관해서는 논란이 있으며, ${ }^{18.19)}$ 본 연구에서는 술후 청력이 불량한 군에서 양호 한 군에 비해 개방동 유돌절제술 환자의 비율이 높았다. 마찬 가지로, 개방동 유돌절제술 환자군에서 예후에 불량한 인자 가 많이 존재하여 술후 청력이 불량하게 나타났다고 생각할 수도 있으나, 병변이 심함을 고려하여 개방동 유돌절제술을 시행하더라도 결과적인 청력호전에는 미치는 영향이 제한적 임을 암시한다고 볼 수 있다.

재수술 여부와 관련해서 유돌절제술을 동반한 예에서는 양군간 유의한 차이를 보이지 않은 반면, 유돌절제술을 동반 하지 않은 예에서는 성공군에서 재수술 비율이 유의하게 낮 았다. 기존 연구들의 경우 술후 청력과 재수술 여부와는 상관 관계가 없다고 보고한 바 있으나, ${ }^{20,21)}$ 본 연구에서는 유돌절 제술의 동반 여부에 따라 상이한 결과를 보였다. 이는 단독 고실성형술 시행 군의 경우 재수술 군에서 유돌절제술을 시 행한 뒤 천공이 재발하여 고실성형술만을 시행한 환자군이 일부 포함되어, 술후 청력에 불리한 인자를 가진 환자군이 초 수술 군에 비해 상대적으로 많이 포함되었기에 이와 같은 결 과가 나타났다고 추측된다.

현재까지 고실 성형술의 예후에 관련된 연구가 있어 왔으 나 연구 대상이 작은 경우가 많았고, 각 연구마다 분석된 인 자의 수가 많지 않으며, 여러 연구에서 상이한 결과를 보이는 경우가 많았다. 이전 선행연구들의 경우 수술 후 예후 평가를 중이염이나 고막유착의 재발, 혹은 천공 등에 의한 재수술의 시행 여부를 지표로 사용하였으며, ${ }^{13,14)}$ 국내에서 고실성형술 후 청각 예후에 대한 연구는 그리 많지 않았다. 본 연구에서 는 술후 예후를 술후 기도-골도차 $10 \mathrm{~dB} \mathrm{HL}$ 이하의 성공적 인 청각결과를 보인 군에게서 어떠한 인자들이 유의하게 높 은 비율로 나타났는지 비교한 연구이다. 본 연구는 상대적으 로 비슷한 조건에서 시행된 1 인 술자에 의한 수술 후 청력결 과를 이용하여 시행된 예후인자 연구이고, 술자에 따른 수기 의 차이 혹은 수술 적응증의 차이의 오류를 보정할 수 있는 비교적 대규모 대상에서 다양한 인자를 분석한 연구라는 장 점이 있다. 이와 함께 유돌절제술 동반 여부에 따른 고막성 형술을 비교한 결과는 기존 연구에 의해 발표되지 않은 새로 운 자료로서 가치가 있다. 
본 연구에서 저자는 제1형 고실성형술 1260 예의 청력 예후 를 분석한 뒤 술전 청력의 영향을 배제한 후 그에 미치는 영 향에 대해 비교해 보았다. 결론적으로, 유양돌기 절제술을 동 반하여도 술후 최종 청력은 단독 고실성형술을 시행한 군보 다 불량하였으며, 유돌절제술의 동반 여부와 관계없이 술중 관찰한 이소골의 움직임은 최종 청력에 영향을 미치는 반면, 술전 외이의 넓이 및 천공의 크기는 그렇지 않았다. 또한 유돌 절제술을 동반한 군에서는 유양동의 함기화 및 이관의 부전 여부가 술후 예후에 영향을 주었지만, 유돌절제술을 동반하 지 않은 경우에서는 그렇지 않았다.

본 연구 결과는 향후 시행될 제1형 고실성형술 및 유돌절제 술을 시행하는 환자에서 예상되는 술후 청력 예후를 추정하 는 데 도움이 될 수 있을 것으로 생각되며, 술전 환자 및 보 호자 상담에 필요한 자료가 될 수 있을 것으로 생각된다.

\section{Acknowledgments}

This study was supported by the National Research Foundation of Korea (NRF) grant funded by the Korean Government (2018R1D1A1B07045305)

The statistical analysis of this study was supported by Division of Biostatistics, Hallym Institute for Clinical Medicine, Hallym University Medical Center.

\section{Author Contribution}

Conceptualization: Hyung-Jong Kim. Data curation: Jun Young Lee. Formal analysis: Jun Young Lee. Funding acquisition: Jun Young Lee. Investigation: Sung-Kwang Hong, Hyo-Jeong Lee, Jong Kyou Lee. Methodology: Hyung-Jong Kim. Writing_original draft: Jun Young Lee. Writing — review \& editing: Hyung-Jong Kim.

\section{ORCID}

Hyung-Jong Kim https://orcid.org/0000-0001-9020-6026

\section{REFERENCES}

1) Brackmann DE. Tympanoplasty with mastoidectomy: Canal wall up procedures. Am J Otol 1993;14(4):380-2.

2) Lade H, Choudhary SR, Vashishth A. Endoscopic vs microscopic myringoplasty: A different perspective. Eur Arch Otorhinolaryngol 2014;271(7):1897-902.

3) Pfammatter A, Novoa E, Linder T. Can myringoplasty close the air-bone gap? Otol Neurotol 2013;34(4):705-10.

4) Sung CM, Kim HY, Park JM, Lee SS, Cho HH, Cho YB. The effect of mastoidectomy combined with tympanoplasty type I on postoperative hearing in chronic otitis media patients older than 65 years. Korean J Otorhinolaryngol-Head Neck Surg 2017;60(12): 626-32.

5) Cody DT, Taylor WF. Tympanoplasty: Long-term results. Ann Otol Rhinol Laryngol 1973;82(4):538-46.

6) Claes J, Van de Heyning PH, Creten W, Koekelkoren E, Van Laer C, De Saegher D, et al. Allograft tympanoplasty: Predictive value of preoperative status. Laryngoscope 1990;100(12):1313-8.

7) Kim CS, Kin DW, Hwang CH, Ahn SH, Park HJ, Kim CH. Postoperative results of tympanoplasty type 1 in adult. Korean J Otolaryngol-Head Neck Surg 2002;45(12):1130-5.

8) Jerger J. Clinical experience with impedance audiometry. Arch Otolaryngol 1970;92(4):311-24.

9) Yue YS, Kim SH, Lee KC, Chu KC. A clinical study on the prognostic factors of tympanoplasty using postoperative tympanogram in chronic otitis media. Korean J OtorhinolaryngolHead Neck Surg 1991;34(1):22-7.

10) Ha SL, Chae GH, Yoon TH. A short-term and long-term follow-up study on change of hearing and tympanogram after tympanoplasty type 1. Korean J Otolaryngol-Head Neck Surg 1998;41(11):1400-5.

11) Yegin Y, Çelik M, Şimşek BM, Olgun B, Karahasanoğlu A, Çolak $\mathrm{C}$, et al. Impact of the degree of the mastoid pneumatization on cartilage type 1 tympanoplasty success. J Craniofac Surg 2016; 27(7):e695-8.

12) Metin M, Kaptan ZK, Dogan S, Yazici H, Bayraktar C, Gocmen H, et al. Effect of preoperative mastoid ventilation on tympanoplasty success. Int J Otolaryngol 2014;2014:169123.

13) Kim YH, Maeng JW, Kim HJ. Eustachian tube function and mastoid pneumatization as prognostic factors of type 1 tympanoplasty. Korean J Otorhinolaryngol-Head Neck Surg 2012;55(5):284-9.

14) Lee MG, Won JY, Kim HJ. A study on prognostic factors of primary and revision myringoplasty. Korean J Otorhinolaryngol-Head Neck Surg 2014;57(7):454-9.

15) Salviz M, Bayram O, Bayram AA, Balikci HH, Chatzi T, Paltura C, et al. Prognostic factors in type I tympanoplasty. Auris Nasus Larynx 2015;42(1):20-3.

16) Wasson JD, Papadimitriou CE, Pau H. Myringoplasty: Impact of perforation size on closure and audiological improvement. J Laryngol Otol 2009;123(9):973-7.

17) Voss SE, Rosowski JJ, Merchant SN, Peake WT. How do tympanicmembrane perforations affect human middle-ear sound transmission? Acta Otolaryngol 2001;121(2):169-73.

18) Kim CS, Chang SO, Lee SS, Hwang CH, Park JB, Won TB. Follow up hearing and complication results of the two surgical techniques in the treatment of adult cholesteatoma. Korean Journal of Otolaryngology-Head and Neck Surgery 2001;44(10):1043-7.

19) Albu S, Babighian G, Trabalzini F. Prognostic factors in tympanoplasty. Am J Otol 1998;19(2):136-40.

20) Prinsley P. Results of revision myringoplasty: Are they different to those of primary myringoplasty? J Laryngol Otol 2017;131(4):316-8.

21) Faramarzi M, Shishegar M, Tofighi SR, Sharouny H, Rajagopalan R. Comparison of grafting success rate and hearing outcomes between primary and revision tympanoplasties. Iran J Otorhinolaryngol 2019;31(102):11-7. 